\title{
Development Of Flag Matching Game To Improve Social Skill Of Mild Mentally Disabled Children In Special Elementary School For Mental Disability
}

\author{
Hedi Ardiyanto Hermawan ${ }^{1}$, Sugiharto ${ }^{2}$, Hari Amirullah Rachman ${ }^{3}$, Setya Rahayu ${ }^{4}$ \\ \{hedi_ardiyanto@uny.ac.id ${ }^{1}$, sugihartoikorsmg@yahoo.com², hari.rachman68@gmail.com ${ }^{3}$, \\ setyafik@yahoo.com ${ }^{4}$ \} \\ Universitas Negeri Yogyakarta ${ }^{1,3}$, Graduate School Universitas Negeri Semarang ${ }^{2,4}$
}

\begin{abstract}
The research intends at developing a game to improve social skills of mild mental disabled children in SDLB/ Special Elementary School for Mental Disability. Research method used was by research and development with development procedures up to large-scale trials. Small-scale trial subjects used one SDLB and large-scale trials using three SDLBs. The four schools/ SDLBs used for the trial were SDLB in Bantul District and Yogyakarta City. Research results show that after going through literature study, expert validation, and small and large scale trials, it produces flag matching game for mild mental disabled children. Flag Matching Game focuses on giving excitement to obeying rules when playing the game, taking turns when playing the game, showing efforts in competitive game and accepting defeat and congratulating competitive game. Effectiveness test is still needed to determine the effectiveness of the game towards improving social skills of mild mentally disabled children.
\end{abstract}

Keywords: social skill, mild mental retardation

\section{Introduction}

In term of its definition, mental disabled children are children who have limitations in cognitive ability. Mental retardation is a disability characterized by sicnificant limitation both in intelectual functioning and in adaptive behaviour as expressed in conceptual, social, and practice adaptive skill [1]. Novan Ardy Wiyani states that there is a grouping of mental disability that is: mild, moderate, serious, and severe [2]. Mild mental disability children are those with education category in IQ range 69- 55 and have the ability to develop communication and communication skills, slightly disturbed muscle coordination, and often undiagnosed.Although children with mental disability have disturbed intelleligence and social adaptation, they have the ability to develop various academic fields of training, social adjustment, and ability to work [3].

Common problem faced by people with mental disability is social adaptation. This difficulty arises because it relates to people with mental disability overcoming limitations in interpersonal relationships with others. To be able to adapt socially good, mental disability must have good social ability. Social skill is the ability to communicate, establish relationships with other people, organize themselves and others, give responses to receive criticism, adjust according to applicable norms and rules [4]. Social skill included comunication skill, 
(Sharing), working together, discussing in community groups [5]. Children with good social skills will be able to express feelings both positive and negative in interpersonal relationships, without having to hurt other people.

Social skills have many supporting components. Snell and Janney in Michael Horvat, Martin E. Block, \& Luke E. Kelly describe the components of social skills including: listening, greeting others, joining, arguing, complimenting, making friends, doing quality work, obey to regulations, using self control, offering help, disagreeing with others, being organized, and talking [6].

Characteristics of mild mentally is disabled children experience weakness in thinking, but on the other hand, other abilities can still be developed, especially those related to the field of skills. In talking, many children can be smooth, but the vocabulary is minimal, they have difficulty in abstract thinking, but they are still able to take academic lessons, both in ordinary schools and in special schools (SLB). The age of intelligence if it is an adult is the same as normal children that is 12 years old.

Social skills of mild mentally disabled children can be taught / trained from family environment and school environment through their academic ability. Once their abilities increased, in living their lives, they will be able to interact with people around them even without guidance or assistance from others. Education to improve social skills in schools can be obtained by mentally disabled children in SLB/ Special School for Disability.

In social field, mild mentally disabled children can be educated to improve mastery of social skills. One way to improve the skills of mild mentally disabled children is to use playing models or games that are made according to the level of growth and development of mild mental disability. Playing or game is an act or voluntary activity done within certain boundaries of space and time that have been determined, according to rules that have been voluntarily accepted but are fully binding, with a purpose in itself, accompanied by feelings of tension and joy, and other awareness from everyday life.

Through playing, mild mentally disabled children are expected to develop both physical and social aspects because one of the benefits of playing is for development of social aspects. To improve social skills of mild mentally disabled children can be done by developing cooperative games. In cooperative playing, mild mentally disabled children are involved in playing with normal children in games that are not competitive. In this cooperative playing activity, division of tasks or division of roles is performed, both for normal children and for children with mild mental disability to achieve an objective; children's social skill.

Movement learning conducted at Special School for Disability/SLB is more focused on improving children's motor skills and have not specifically provided activities to observe social skills. The aim of this research is to develop a flag matching game that can stimulate ability of several components of social skills. Research benefits are to improve some social ability components for mild disabled children at SDLB. Flag matching game is expected to be able to improve children's social skills. In addition, this game can also improve children's cognitive abilities.

\section{Method}

\subsection{Research Procedure}

In general, this development research was done by following the steps which include: (a) Preliminary study, (b) Development, and (c) Field Trial/ Test. 
1. Preliminary study, including: a. Literature study, reviewing relevant theories and results of research, b. Field studies, conducting surveys, reviewing the characters of research subject, and looking at possibilities if the research product in the form of game model is applied.

2. Development, including: a. Objective analysis, formulating the objectives to be achieved from development research, b. Capability analysis, estimating funds, energy, and time needed to do the development research, c. Development procedures (design development): (a) make product designs to be developed. (b) determine the research facilities and infrastructure to be used. (c) determine the stages of implementation of design tests in field and d. Expert validation, conduct validation by involving adaptive physical education experts and material experts.

3. Field Tests, including: a. Small-scale field testing is an initial field test involving $1 \mathrm{SLB} / \mathrm{Special}$ School for Disability, and b. Large-scale field testing is field test with greater number of subjects than small-scale field trials involving 3 SLBs.

\subsection{Data Source And Research Subject}

Data Source. The data produced were qualitative data and quantitative data. Qualitative data were taken from preliminary survey the results in SLB/ School for Disability for teachers to investigate real conditions of Physical Education, Sport, and Health/ PJOK learning process. Qualitative data were also obtained from initial draft validation results of activity model game to improve skills of small group trial and large group trial results.

Research Subject. Trial subjects in this development research done were students in SLB/ School for Disability from 4 schools, they were: (a) 1 SLB for small-scale trial, (b) 3 SLBs for large-scale trial. The subjects of small-scale trial used students from SLB 2 Bantul with total 10 students. While the large-scale trials used students from three SLBs; SLB 1 Yogyakarta 10 students, SLB 2 Yogyakarta 10 students, and SLB Pembina Yogyakarta 10 students.

Technique and Data Collection Instrument. To get data on the process and results to be achieved, researchers used data collection technique with observation. The observation sheet used is to see social skills and to assess the products developed.

Data Analysis Technique. Data analysis technique used was by quantitative data analysis to analyze observation sheet data as a basis that can be tested on small scale or large scale. This analysis was done on experts' observation result data in giving suggestions or inputs and revisions to the model. This compiled model was considered feasible to be testeded on small scale if the score achieved reached minimum standard of feasibility. score was obtained from filling out the questionnaire that had been given, there were four rating scales in the questionnaire; they were 1, 2, 3 and 4 . Then the scale was interpreted into the scoring system as in Table 1 below:

Table 1. Tabulation of Questionnaire Score

\begin{tabular}{cccc}
\hline No & Scale on Questionnaire & Result Score of Conversion & $\begin{array}{c}\text { Maximum Score } \\
\text { (14 quesitons) }\end{array}$ \\
\hline 1 & 4 & 4 & 56 \\
2 & 3 & 3 & 42 \\
3 & 2 & 2 & 28 \\
4 & 1 & 1 & 14 \\
\hline
\end{tabular}


From the table above, the difference in scores between the maximum top and the bottom scores is 42 points, while the midpoint of the two scores is 35 . In this research, score 35 was set as a standard for a model to be considered feasible of testing in the field. If the score taken by the model was more than $35(>35)$, the model was considered feasible to be tested in the field, whereas if the model reached score less than $35(\leq 35)$ then this was considered as not feasible for testing in field.

\section{Research Result}

\subsection{Product Design Plan}

Based on the need analysis, literature review, and relevant researches, this generates three developed aspects; game design, game implementation, and observation of social skills. In development of game design, the aspects developed are objectives of the game, game material, game equipment, and assessment of developed components in the game. In the development of game implementation is directed at games that are mixed in flag matching games. The initial draft of the game products is as follows:

\subsection{Flag Matching Game}

Game Description. Flag Matching Game is a game that is designed to provide opportunities for mentally disabled children to grow habits of obeying rules of game, taking turn when playing, showing efforts in a game, and accepting defeat, and congratulating to the winner in a competition. The game is played by matching picture flag in pairs. This game is contested and the pair matching the flag first is the winners. After the winners finish matching the flag first, the losing pair must congratulate the winning pair. This game is done repeatedly.

Game Objectives. Objectives of the game are:

1. Obeying rules when playing game.

2. Taking turn when playing game.

3. Showing efforts in competitive game.

4. Accepting defeat and congratulating game winners.

\section{Fields, Equipment and Supply}

Game Field. The playing field is rectangular with $13 \mathrm{~m}$ size and divided into parts of the start and finish fields. Starting point is at the end of the field, while finish is at the center of the field. The picture of the game field can be seen as shown figure 1 . 

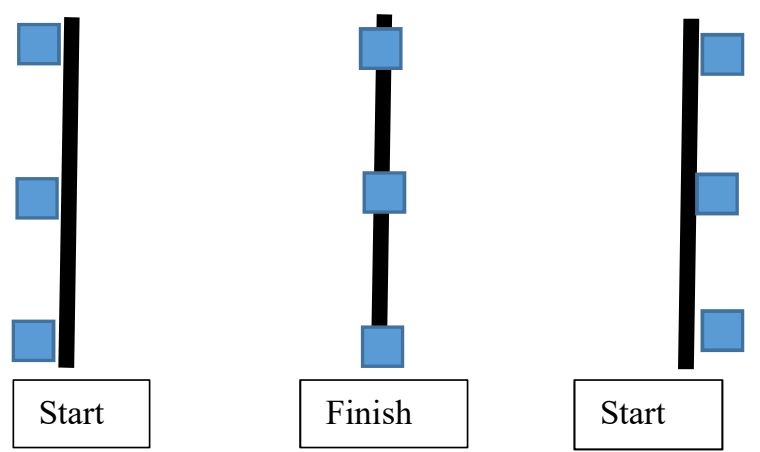

Figure 1. Flag Matching Game Figure

Flags with Various Colors and Pictures.

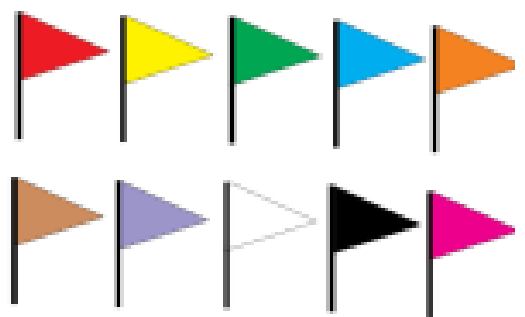

Figure 2. Game Flags

Box to Put the Flags.

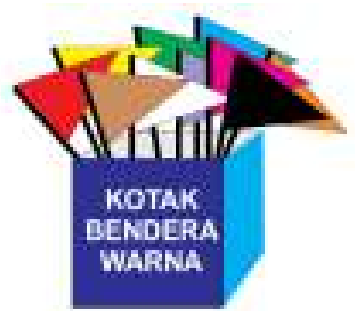

Figure 3. Flag Box

\section{Game Instructions}

1. The game starts by warming up.

2. Students are divided into two groups with five children each group.

3. After warming up, the students are aligned with the formation facing each other in game field that has been prepared.

4. Each pair gets the same number and color flags.

5. The game starts with whistle blast.

6. After signs that the game starts, one of students in the group shows one of flags to his/ her friend. The job of his/her partner is to look for the same flag that his/ her friend takes. After the flag matches, then the partner runs towards the center to put the flag on the box provided. 
7. The game is played until the flag provided is completed.

8. The pair who succeeds to match all the flags for the first time is the pair that wins. The winning pair deserves congratulations from the other pair who lose.

9. The winning pair/group receives an asterisk (star sign)

10. The game is repeated several times.

11. Picture of the game is as follows figure 4.

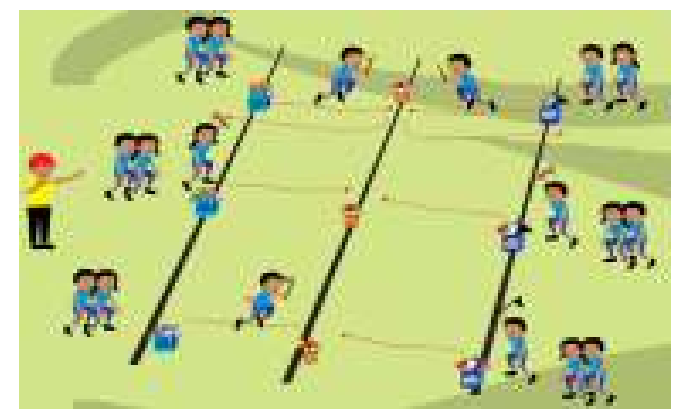

Figure 4. Flag Matching Game

\section{Evaluation}

1. Students obey the rules when playing the game.

2. Students take turns when playing the game.

3. Students show efforts in the competitive game.

4. Students accept defeat and congratulate the competitive game.

\section{Expert Validity}

Before being tested in the field, both small scale trial and large scale trial, the initial draft game activity model to improve social skills of mild mentally disabled children in SDLB/ Special Elementary School for Disability was validated by 2 material experts and 2 SLB practitioners/ teachers. Validation of material experts was done by Prof. Dr. Siswantoyo, M.Kes., AIFO. and Dr. Sumaryanti, M.Kes., adaptive physical education expert. Validation was done by showing the initial draft of the product accompanied by assessment sheet from the game. Product evaluation sheets used Likert scale sheets on a scale 1 to 4 . From the results of the initial assessment, the initial draft of the game product still needs to be revised. Material experts still wanted to add and reduce the concept of the model. Suggestions from experts were in the form of written notes. The complete suggestions from the material experts and practitioners can be presented below.

Table 2. Validity Input of Initial Draft of Game Activity Model to Improve Social Skill of Students with Mild Mental Disability in SDLB/Elementary School for Disability from Expert

\begin{tabular}{|c|c|}
\hline Name of Game & Expert Suggestion \\
\hline 1. Flag Matching Game & $\begin{array}{l}\text { - Less activities done by students characterizing the game } \\
\text { - To show the characteristics of the game, games are arranged in form } \\
\text { race. } \\
\text { - It is better to use media that shows tasks that are then assigned to studer } \\
\text { to look for words. } \\
\text { - Communication is considered in the preparation of the game }\end{array}$ \\
\hline
\end{tabular}


Based on suggestion/ input from material experts and practitioners, researchers immediately conducted revisions of the first phase of initial draft game activity model to improve the social skills of mild mentally disabled students in SDLB. The revised results are based on written records and discussion results among researchers, material experts, and practitioners presented below:

Table 3. Initial Draft Revision of Game Activity Model to Improve Social Ability of Mild Mental Disabled Children in SDLB/ Elementary School for Disability

\begin{tabular}{ccc}
\hline No & Name of Game & \multicolumn{1}{c}{ First Phase Revision of Initial Draft } \\
\hline 1. & Flag Matching Game & - Revised by using animal pictures to be named later. \\
& & - The number of images used is 3. \\
& & - The distance between the start and the place where the letters a \\
& & placed is determined. \\
& & Do not use white board but is replaced by using styrofoam. \\
\hline
\end{tabular}

The assessment results from experts and practitioners in assessment sheet are as follows:

Table 4. The assessment results from experts and practitioners

\begin{tabular}{|c|c|c|c|c|c|}
\hline \multirow[t]{2}{*}{ No } & \multirow[t]{2}{*}{ Assessed Aspects } & \multicolumn{4}{|c|}{$\begin{array}{c}\text { Expert and Teache } \\
\text { Assessment Score }\end{array}$} \\
\hline & & A1 & $\mathbf{A 2}$ & G1 & G2 \\
\hline 1. & Accuracy of choosing game model for students. & 3 & 3 & 3 & 3 \\
\hline 2. & Clarity of instructions for implementing the game. & 4 & 3 & 3 & 3 \\
\hline 3. & Suitability of tools and facilities used. & 4 & 3 & 3 & 3 \\
\hline 4. & Ease of game models for students to play. & 4 & 4 & 4 & 3 \\
\hline 5. & Suitability of game model with student characteristics. & 3 & 4 & 3 & 3 \\
\hline 6. & The game encourages the development of students' physical aspects. & 4 & 4 & 4 & 4 \\
\hline 7. & The game encourages the development of students' cognitive aspects. & 2 & 3 & 3 & 4 \\
\hline 8. & $\begin{array}{l}\text { The game encourages the development of psychomotor aspects } \\
\text { students which include } \\
\text { students' locomotor, non- locomotor and manipulative movements. }\end{array}$ & 4 & 4 & 4 & 4 \\
\hline 9. & The game encourages the development of students' affective aspects. & 3 & 2 & 3 & 3 \\
\hline 10. & The game encourages students' competitive abilities. & 3 & 3 & 3 & 4 \\
\hline 11. & The game model can be played by male and female students. & 3 & 4 & 4 & 4 \\
\hline 12. & The game model can stimulate students to actively move. & 4 & 3 & 4 & 4 \\
\hline 13. & The game model can improve students' social skills. & 3 & 3 & 3 & 3 \\
\hline 14. & The game model is safe to play by students. & 3 & 3 & 3 & 3 \\
\hline & tal Score & 47 & 46 & 47 & 48 \\
\hline & ean & 3.4 & 3.29 & 3.4 & 3.43 \\
\hline
\end{tabular}

From the data above, it shows that the stringing word game model falls into good category so that it can be followed by small group trials.

Small Scale Trial. Small group trial on flag matching game model products to improve social skills of mild mentally disabled students in SLB was held at SLB 2 Bantul Yogyakarta with total 10 students. There were three practitioners involved in the small group trial whose task was to assess the game activity model. The three practitioners were the same as those in 
charge of the initial draft validation stage of the product. At small-scale trial stage, there were only two suggestions from the practitioners, they were: the distance between one group to another was widened to reduce looking one another of the results of each group. The suggestions from the practitioners were then used as basis for perfecting flag matching game activity model.

Table 3. Implementation Test Result of Physical Education Model in Small Scale Trial Group

\begin{tabular}{ccc}
\hline No & Name of Game & $\begin{array}{c}\text { School Trial Location } \\
\text { SLB 2 Bantul }\end{array}$ \\
\hline 1. & Flag Matching Game & 3.71 \\
& Mean & 3.71 \\
\hline
\end{tabular}

Table 3 shows that the results of small-scale trial of perceptual motor-based physical activity model has reached 3.8 with criteria of Good. This means that the game activity model can be followed up to large-scale trial.

Large Scale Trial. Schools for conducting large group trial were SLB 1 Yogyakarta, SLB 2 Yogyakarta and SLB Pembina Yogyakarta. In the large group trial, the researchers used the same three practitioners with those in the small group trial. The practitioners also provided inputs and suggestions for refining the flag matching game model, they were: pictures were made clearer so that they were clearly understood.

Table 4. Test Result of Game Model Implementation of Large Scale Trial

\begin{tabular}{ccccc}
\hline No & Name of Game & \multicolumn{3}{c}{$\begin{array}{c}\text { School Trial Location } \\
\end{array}$} \\
& SLB 1 YogyakartaSLB 2 Yogyakarta & $\begin{array}{c}\text { SLB Pembina } \\
\text { Yogyakarta }\end{array}$ \\
\hline 1. & Flag Matching Gan & 4,0 & 3.71 & 3.71 \\
& Average & 4,0 & 3.71 & 3.71 \\
\hline
\end{tabular}

From the Table above, it is known that the results of large group trial of games activity model has reached 3.8 or with the Good criteria. The results achieved in the large group trial is better than the results of the small group trial, even though the criteria are the same. The increase of the trial results can be interpreted that the stringing words game model gets more and more inputs/ suggestions that can make it better.

\section{Discussion}

Flag Matching Game is a game using various colors of flags which are then matched by students in pairs in play group. Flag Matching Game focuses on giving excitement to obeying rules when playing the game, taking turns when playing the game, showing efforts in competitive game and accepting defeat and congratulating competitive game. Flag matching game gives stimulation to be able to improve some social skill components in mild mental disabled children in SDLB. Social skills have functions as a means to obtain good relationships in interacting with others. For examples are saving the environment, helping others, cooperating, making decisions, communicating, entrepreneurship, and participating 
[7]. To improve social skills can be done by using games that match the characteristics of the children.

Bodrova \& Leong state that playing has a relationship with cognitive development and social skills needed in children learning process [8]. Such as playing grows memory, selfmanagement, communicates verbally, and recognizes symbols. Eberle states that play offers benefits in developing mental, physical, and social skills [9].

Mental disabled children are children who have cognitive limitations and social skills. Through game activities mental disabled children are expected to be able to improve the social skills. Bacsata suggests that adaptive behavior consists of active and passive conversations, speaking personal safety, mobility, are collection of skills needed for mental disability [10].

Flag matching game is developed with regard to social skill components. By playing flag matching game, children also do some social skill components such as taking turns when playing a game, showing effort in a competitive game, accepting losses, and congratulating competitive game.

This game novelty is this game while observing several social skill components done by mental disabled children. The benefits obtained by mental disabled children are that children feel happy and simultaneously develop several components of social skills.

\section{Conclusion}

Children with mental disability usually have disorders of intellectual function and adaptive behavior in conceptual, social and adaptive practice skills. Having good social skills in mentally disabled children will have the function as a means to obtain good relationships in interacting with others. Games are very important for children's development, because playing can contribute to cognitive, physical, social and emotional and well-being. Flag Matching Game is a game using various colors of flags which are then matched by students in pairs in play group. Flag Matching Game focuses on giving excitement to obeying rules when playing the game, taking turns when playing the game, showing efforts in competitive game and accepting defeat and congratulating competitive game. Flag matching game gives stimulation to be able to improve some social skill components in mild mental disabled children in SDLB. 


\section{Reference}

[1] Hooseinkhanzadeh A.A.: Identification of Social Skill Defisit in Student With Mental Retardation. International Journal of Psychologi and Behavioral Research. Vol 3(5). Pp. 402411 (2014)

[2] Novan Ardy Wiyani: Buku Ajar Penanganan Anak Usia Dini Berkebutuhan Khusus. Legally Free Book. Yogyakarta (2014)

[3] Isti Widyanti: Pembelajaran Melalui Stimulus Benda Langit Untuk Mengembangkan Kemampuan Kognitif Siswa Tunagrahita Ringan di SDLB Negeri Purwakarta. Diakses melalui https://www.google.com/url? Chapter1.pdf\&ei. (2014)

[4] Aindha V. Katoro: Perbedaan Keterampilan Sosial Ditinjau dari Sistem Pendidikan. Surakarta: Skripsi (2013)

[5] Putri A. Perdani. Peningkatan Keterampilan Sosial Melalui Metode Bermain Permainan Traditional Pada Anak TK B. Jurnal Pendidikan Usia Dini. Vol 7. Pp. 335-350. (2013)

[6] Michael Horvat. Martin E. Block. Luke E. Kelly. Developmental and Adapted Physical Activity Assesment. Legally Free Computer Book, US (2007)

[7] Sri Muji Wahyuti. Pengembangan Keterampilan Sosial Siswa Melalui Pemahaman Multikultural dalam Bimbingan dan Konseling. Jurnal Profesi Pendidik. Vol 2. Pp. 26-34. (2015)

[8] Bodrova, E. \& Leong, D.J. Why Children Need Play. Scholastic Early Childhood Today. 20, Pp.: 6 (2005)

[9] Eberle, S.G. Playing with the Multiple Intelligences. American Journal of Play, Vol 4 Pp. 19 (2011)

[10] Baczala Ditta. Social Skill of Individu With Intelectual Disability. International Journal of Psycho-Educational Sciences. Vol 5 Pp. 68-77. (2016) 